\title{
Robiginitalea biformata gen. nov., sp. nov., a novel marine bacterium in the family Flavobacteriaceae with a higher $\mathrm{G}+\mathrm{C}$ content
}

\author{
Jang-Cheon Cho and Stephen J. Giovannoni \\ Department of Microbiology, Oregon State University, Corvallis, OR 97331, USA
}

Stephen J. Giovannoni

steve.giovannoni@

oregonstate.edu

\begin{abstract}
Two Gram-negative, chemoheterotrophic, non-motile, rust-coloured, marine strains were isolated from the western Sargasso Sea by high-throughput culturing. Characterization of the two strains by polyphasic approaches indicated that they are members of the same species. Phylogenetic analyses based on 16S rRNA gene sequences using three treeing algorithms revealed that the strains formed a coherent and novel genus-level lineage within the family Flavobacteriaceae. The dominant fatty acids were branched or hydroxy acids, i15:0, i15:1 and 3-OH i1 7: 0 being the most abundant. The higher DNA G $+\mathrm{C}$ content of the strains (55-56 mol\%) clearly differentiated them from other genera of the family Flavobacteriaceae (27-44 mol\%). It is proposed, from the polyphasic evidence, that the strains be placed into a novel genus and a novel species named Robiginitalea biformata gen. nov., sp. nov., with strain

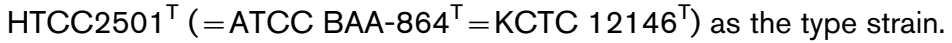

The family Flavobacteriaceae (Reichenbach, 1989; Bernardet et al., 2002) is one of the main phylogenetic lineages within the phylum 'Bacteroidetes' (Garrity \& Holt, 2001), members of which generally comprise $6-30 \%$ of total bacterial communities in sea water, as determined by fluorescence in-situ hybridization (Glöckner et al., 1999; Eilers et al., 2000; Cottrell \& Kirchman, 2000). According to the emended description of the family Flavobacteriaceae by Bernardet et al. (2002), members of the family are Gramnegative, non-spore-forming, short to moderately long rods that cannot degrade crystalline cellulose. Their major cellular fatty acids are branched or hydroxy fatty acids, with high levels of i15:0 and 3-OH i17:0, and the DNA $\mathrm{G}+\mathrm{C}$ contents range from 27 to $44 \mathrm{~mol} \%$. In the last few years, polyphasic approaches (Vandamme et al., 1996) powered by $16 \mathrm{~S}$ rRNA gene sequence-based phylogeny have rapidly expanded the discovery and description of members of the family Flavobacteriaceae, including Gelidibacter and Psychroserpens (Bowman et al., 1997), Polaribacter (Gosink et al., 1998), Psychroflexus (Bowman et al., 1998), Salegentibacter (McCammon \& Bowman, 2000), Cellulophaga (Johansen et al., 1999), Arenibacter (Ivanova et al., 2001), Muricauda (Bruns et al., 2001), Aequorivita (Bowman \& Nichols, 2002), Gillisia (Van Trappen et al., 2004), Vitellibacter, Ulvibacter and Mesonia (Nedashkovskaya et al., 2003a, b, 2004) and Croceibacter (Cho \& Giovannoni,

Published online ahead of print on 9 January 2004 as DOI 10.1099/ ijs.0.03023-0.

The GenBank accession numbers for the 16S rRNA gene sequences of strains $\mathrm{HTCC} 501^{\top}$ and HTCC2514 are AY424899 and AY424900. 2003a), most of which were cultivated from marine environments. We have isolated and characterized several novel marine strains within the family Flavobacteriaceae from a series of high-throughput culturing (HTC) experiments. In this study, we describe two of these strains, HTCC $2501^{\mathrm{T}}$ and HTCC2514, as members of a new genus in the family Flavobacteriaceae. The two strains were isolated from the Sargasso Sea (Atlantic Ocean), using HTC, and were maintained on Marine agar 2216 (Difco) at $30^{\circ} \mathrm{C}$ as described previously (Cho \& Giovannoni, 2003a).

\section{Phylogeny}

16S rRNA gene fragments were generated by a PCR and directly sequenced as described by Cho \& Giovannoni (2003a). Nearly full-length sequences of the 16S rRNA gene, 1434 and 1454 bp for strains HTCC2501 ${ }^{\mathrm{T}}$ and HTCC2514, respectively, were aligned using the ARB software package (Ludwig et al., 1998) and 1169 unambiguously aligned nucleotide positions were used for phylogenetic analyses in PAUP $^{\star} 4.0$ beta 10 . Phylogenetic trees were inferred by neighbour-joining with the Kimura two-parameter model, maximum parsimony and maximum likelihood (tree bisectionreconnection-branching; a transition/transversion ratio of 1.326). The tree topologies from neighbour-joining and maximum parsimony were evaluated by bootstrap analyses based on 1000 resamplings. The sequence similarity between strains HTCC2501 ${ }^{\mathrm{T}}$ and HTCC2514 was $99 \cdot 99 \%$ (only 2 nucleotide differences), so they were considered to be the same species using this criterion as well as on the basis of their DNA relatedness $(94 \cdot 6 \pm 3 \cdot 9 \%$; for methods, see Cho \& Giovannoni, 2003b). None of the taxa with validly 
published names showed more than $90 \% 16 \mathrm{~S}$ rRNA gene sequence similarity to the strains. The two HTCC isolates formed a distinct lineage within the family Flavobacteriaceae (Fig. 1), the most closely related genera being Zobellia $(88 \cdot 6-89 \cdot 7 \%)$, Arenibacter $(88 \cdot 3-88 \cdot 4 \%)$, Aequorivita $(88 \cdot 3-89 \cdot 2 \%)$ and Vitellibacter $(87 \cdot 8-88 \cdot 0 \%)$, and the lineage did not associate significantly with any of the described genera in the family. The branching orders and phylogenetic relationships between the strains and Muricauda-Zobellia-Arenibacter-Aequorivita-Vitellibacter were well conserved in all three phylogenetic trees (Fig. 1). The robustness of the phylogenetic relationships and the low sequence similarities between the strains and the other genera demonstrate that the two novel HTCC isolates represent a new genus in the family Flavobacteriaceae.

\section{Phenotypic characteristics}

Tests used for phenotypic characterizations were performed as described in previous studies (Cho \& Giovannoni, 2003a, b), except that the incubation temperature used was $30^{\circ} \mathrm{C}$. Biochemical tests were carried out using API 20NE strips (bioMérieux). Custom-made 48-well microplates containing 47 different carbon compounds at a final concentration of $0.2 \%(\mathrm{w} / \mathrm{v}$ or $\mathrm{v} / \mathrm{v})$ were used to test sole-carbon-source utilization. Cell morphology varied clearly with the growth stage of the cells. Cells in early exponential phase (1-2 days

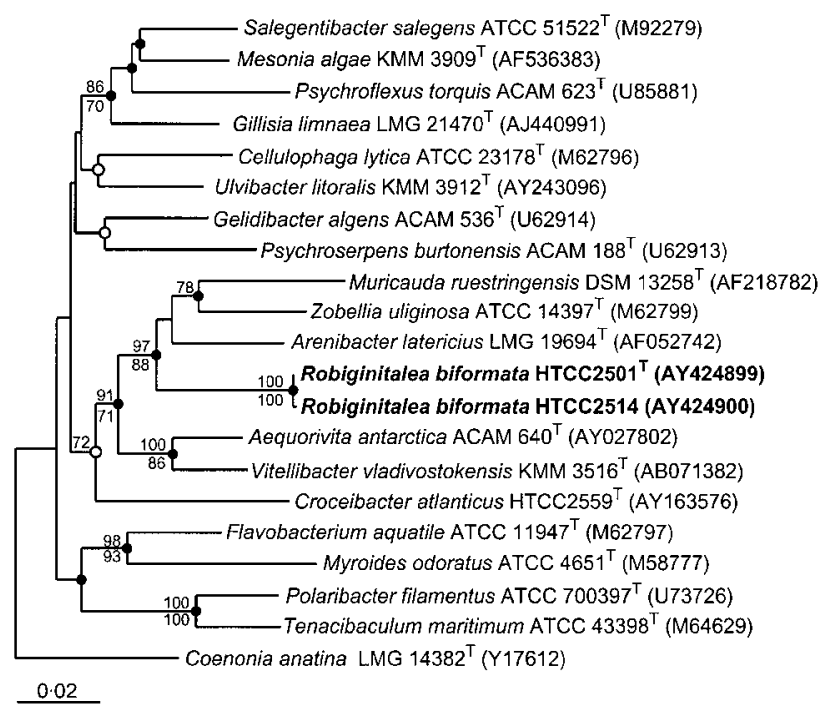

Fig. 1. Neighbour-joining $16 \mathrm{~S}$ rRNA-based phylogenetic tree showing relationships between the marine HTCC isolates and representatives of the family Flavobacteriaceae. Bootstrap proportions above $70 \%$ from both neighbour-joining (above nodes) and maximum parsimony (below nodes) are shown. Closed and open circles respectively indicate nodes recovered reproducibly by all treeing methods and by two treeing methods. Coenonia anatina LMG $14382^{\top}$ (Y17612) was used as an outgroup to define the root of the tree. Bar, 0.02 substitutions per nucleotide position. incubation) were predominantly straight rods, $1 \cdot 6-5 \cdot 6 \mu \mathrm{m}$ long and $0 \cdot 3-0 \cdot 7 \mu \mathrm{m}$ wide, while those in stationary phase (5-8 days incubation) tended to transform into coccoid cells that were $0 \cdot 6-1 \cdot 2 \mu \mathrm{m}$ in diameter (Fig. 2). This pleomorphic property has been reported for other genera of the family Flavobacteriaceae, including Gelidibacter and Psychroserpens (Bowman et al., 1997). Colonies on Marine agar 2216 were $1 \cdot 0-2 \cdot 0 \mathrm{~mm}$ in diameter, rusty orangecoloured, uniformly circular, pulvinate, opaque and possessed a smooth surface. Gliding motility and flagella were not observed. They did not grow under either strictly anaerobic conditions or microaerobic conditions. The temperature range for growth was $10-44^{\circ} \mathrm{C}$, with optimum growth at $30^{\circ} \mathrm{C}$. No growth was observed at 4 or $48^{\circ} \mathrm{C}$. The $\mathrm{pH}$ range for growth was $\mathrm{pH} 6 \cdot 0-9 \cdot 0$ (optimum $8 \cdot 0-8 \cdot 5$ ). The isolates were moderately halophilic, showing good growth at $\mathrm{NaCl}$ concentrations of $0 \cdot 25-10 \%$ (w/v; optimum $2 \cdot 5 \%)$. Both strains produced carotenoid pigments with wavelength absorbance spectral peaks at 339 and $457 \mathrm{~nm}$, with a major peak at $457 \mathrm{~nm}$. The bathochromic shift test results indicated that flexirubin pigments were absent. Other phenotypic results for biochemical characteristics, solecarbon-source utilization, antibiotic susceptibility and degradation of macromolecules are given in Table 1 and in the species description.
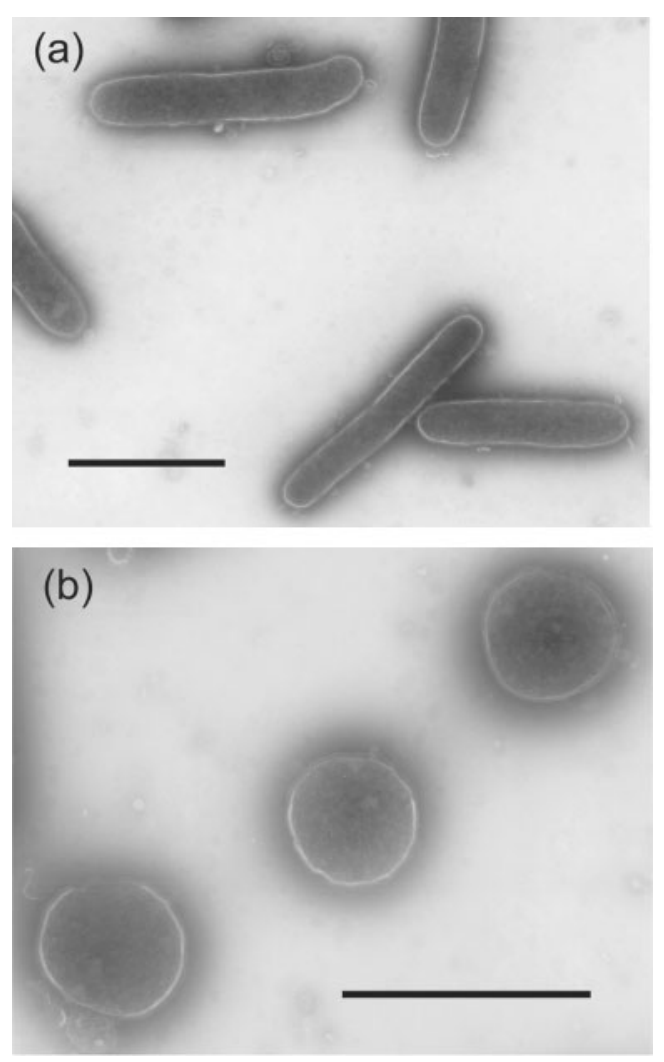

Fig. 2. Electron micrographs of negatively stained cells of strain $\mathrm{HTCC} 2501^{\top}$ in exponential phase (a) and stationary phase (b). Bars, $2 \cdot 0 \mu \mathrm{m}$. 
Table 1. Phenotypic characteristics of Robiginitalea biformata gen. nov., sp. nov. HTCC2501 ${ }^{\top}$ and $\mathrm{HTCC} 514$

Where two results are given, they refer to strains HTCC2501 $/$ HTCC2514. Otherwise, the two strains show the same response.

\begin{tabular}{|c|c|}
\hline Characteristic & R. biformata $(n=2)$ \\
\hline \multicolumn{2}{|l|}{ Biochemical properties (API 20NE) } \\
\hline Catalase, oxidase, aesculin hydrolysis, $\beta$-galactosidase & + \\
\hline \multicolumn{2}{|l|}{ Sole-carbon-source utilization } \\
\hline $\begin{array}{l}\text { D-Ribose, D-xylose, D-glucose, D-fructose, L-sorbose, D-mannose, sucrose, } \beta \text {-lactose, D-trehalose D-cellobiose, } \\
\text { D-maltose, D-melibiose, D-raffinose, } N \text {-acetyl D-glucosamine, succinic acid, propionic acid, lactic acid, } \\
\text { L-glutamate, L-ornithine, L-proline, L-serine }\end{array}$ & + \\
\hline $\begin{array}{l}\text { DL-Glyceraldehyde, D-arabinose, D-galactose, L-rhamnose, D-sorbitol, adonitol, methanol, ethanol, glycerol, } \\
\text { pyruvic acid, itaconic acid, citric acid, gluconic acid, D-malic acid, malonic acid, formic acid, L-alanine, } \\
\text { L-lysine, D-glucosamine, L-alanine, L-leucine, L-isoleucine, glycine, L-arginine }\end{array}$ & - \\
\hline D-Melezitose & $+1-$ \\
\hline D-Mannitol, $m$-inositol & $-1+$ \\
\hline Nalidixic acid, tetracycline, erythromycin, rifampicin, benzylpenicillin & + \\
\hline $\begin{array}{l}\text { Chloramphenicol, kanamycin, carbenicillin, streptomycin, ampicillin, puromycin, vancomycin, gentamicin, } \\
\text { cycloheximide }\end{array}$ & - \\
\hline \multicolumn{2}{|l|}{ Fatty acid composition $(\%)^{\star}$} \\
\hline $15: 0$ & $5 \cdot 5$ \\
\hline $16: 0$ & $1 \cdot 3$ \\
\hline $\mathrm{i} 15: 0$ & $26 \cdot 0$ \\
\hline $\mathrm{a} 15: 0$ & $3 \cdot 7$ \\
\hline i15 : 1 & $17 \cdot 2$ \\
\hline i17 : 0 & $0 \cdot 9$ \\
\hline 2-OH $17: 0$ & $1 \cdot 2$ \\
\hline
\end{tabular}

${ }^{\star}$ Fatty acids comprising more than $1 \%$ of the total content are shown. The following fatty acids were rarely present in the strains: $14: 0$, i13:0,

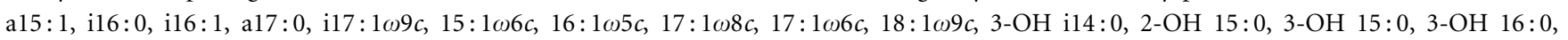
$3-\mathrm{OH}$ i16:0 and 3-OH $17: 0$.

\section{Chemotaxonomy}

The DNA G + C content was analysed by HPLC according to Mesbah et al. (1989), using a Platinum EPS reverse-phase C18 column (Alltech Associates), and phage $\lambda$ DNA was used as a standard throughout the analyses. The DNA G $+C$ contents of strains HTCC $2501^{\mathrm{T}}$ and HTCC2514 were respectively $56 \cdot 4 \pm 0 \cdot 2$ and $54 \cdot 7 \pm 0 \cdot 4 \mathrm{~mol} \%$. The G+C content of the strains was at least $10 \mathrm{~mol} \%$ higher than that of other members of the family Flavobacteriaceae (Table 2). Cellular fatty acid methyl esters were prepared and analysed using GC according to the instructions of the Microbial Identification System (MIDI). The predominant fatty acids in the strains were i15:0 (24-28\%), i15:1 (14-21\%) and 3-OH i17: 0 (25-27\%) (Table 1). The major fatty acid types were branched acids and hydroxy acids, which comprised $75 \cdot 7-77 \cdot 9 \%$ of total fatty acids. The fatty acid profiles of the two strains were almost identical to each other. Although the fatty acid profile of the HTCC isolates was similar to that of Muricauda ruestringensis, it differed significantly from those of the other phylogenetically related genera in the family Flavobacteriaceae (Table 2).

\section{Taxonomic conclusions}

The two strains showed almost the same phenotypic characteristics except for differences in the utilization pattern for three carbon compounds, and shared very similar genotypic characteristics, such as $>99 \% 16 \mathrm{~S}$ rDNA sequence similarity and $>90 \%$ DNA-DNA hybridization, so they were regarded as members of the same species (Wayne et al., 1987). Polyphasic taxonomy based on $16 \mathrm{~S}$ rRNA gene sequence analyses (Fig. 1) and phenotypic characteristics together with chemotaxonomic data (Tables 1 and 
Table 2. Differential characteristics of $R$. biformata from phylogenetically related species in the family Flavobacteriaceae

Species: 1, Robiginitalea biformata gen. nov., sp. nov. (this study); 2, Muricauda ruestringensis (Bruns et al., 2001); 3, Zobellia uliginosa (Barbeyron et al., 2001; Reichenbach, 1989); 4, Arenibacter latericius (Ivanova et al., 2001); 5, Aequorivita antarctica (Bowman \& Nichols, 2002); 6, Vitellibacter vladivostokensis (Nedashkovskaya et al., 2003a); 7, Croceibacter atlanticus (Cho \& Giovannoni, 2003a). Symbols: + , positive; -, negative; V, variable; -, not detected; ND, not determined.

\begin{tabular}{|c|c|c|c|c|c|c|c|}
\hline Characteristic & 1 & 2 & $3 \dagger$ & 4 & 5 & 6 & 7 \\
\hline Flexirubin & - & - & + & - & - & + & - \\
\hline Gliding motility & - & - & + & - & - & - & - \\
\hline Reaction to oxygen ${ }^{\star}$ & A & $\mathrm{F}$ & $\mathrm{A}$ & A & A & A & A \\
\hline Growth at $42^{\circ} \mathrm{C}$ & + & - & + & - & - & + & - \\
\hline Nitrate reduction & - & - & + & + & - & - & - \\
\hline Oxidase/catalase production & $+1+$ & $+1-$ & $+1+$ & $+1+$ & $\mathrm{ND} /+$ & $+1+$ & $-1+$ \\
\hline$\beta$-Galactosidase & - & $\mathrm{ND}$ & + & $\mathrm{V}$ & - & - & - \\
\hline Glucose acidification & - & - & + & $\mathrm{ND}$ & - & - & - \\
\hline \multicolumn{8}{|l|}{ Degradation of: } \\
\hline Starch & + & - & $\mathrm{V}$ & - & + & - & + \\
\hline Aesculin & + & $\mathrm{ND}$ & + & - & + & ND & - \\
\hline Gelatin & - & - & + & - & + & + & + \\
\hline DNA & - & ND & + & - & - & + & + \\
\hline Cellulose & - & - & - & - & - & - & - \\
\hline Urea & - & ND & - & + & $\mathrm{V}$ & - & + \\
\hline Arginine & - & + & - & - & - & ND & + \\
\hline \multicolumn{8}{|l|}{ Major fatty acids (\%): } \\
\hline $15: 0$ & $5-6$ & $1 \cdot 1$ & $10 \cdot 4$ & $13 \cdot 3$ & $0 \cdot 6$ & $3 \cdot 7$ & $3 \cdot 9$ \\
\hline $\mathrm{i} 15: 0$ & $24-28$ & $15 \cdot 5$ & $38 \cdot 2$ & $17 \cdot 3$ & $7 \cdot 6$ & $68 \cdot 8$ & $13 \cdot 3$ \\
\hline a15:0 & $3-4$ & $2 \cdot 4$ & - & $6 \cdot 6$ & $15 \cdot 7$ & $8 \cdot 4$ & $1 \cdot 6$ \\
\hline $\mathrm{i} 15: 1$ & $14-21$ & $16 \cdot 3$ & $8 \cdot 7$ & $19 \cdot 3$ & $9 \cdot 5$ & $2 \cdot 4$ & $9 \cdot 1$ \\
\hline a15: 1 & $0 \cdot 3-0 \cdot 6$ & $0 \cdot 6$ & - & $1 \cdot 7$ & $16 \cdot 0$ & - & - \\
\hline $16: 1 \omega 7 c$ & - & - & $9 \cdot 8 \ddagger$ & $11 \cdot 0$ & $7 \cdot 8$ & $0 \cdot 1$ & - \\
\hline 3-OH i15:0 & $4 \cdot 3$ & $4 \cdot 9$ & - & - & $5 \cdot 4$ & $1 \cdot 6$ & $4 \cdot 3$ \\
\hline 3-OH i16:0 & $0 \cdot 9$ & $2 \cdot 8$ & - & - & $9 \cdot 2$ & - & $4 \cdot 4$ \\
\hline 3-OH i17:0 & $25-27$ & $28 \cdot 7$ & $16 \cdot 1$ & - & $2 \cdot 0$ & $0 \cdot 8$ & 28 \\
\hline $\mathrm{G}+\mathrm{C}$ content $(\mathrm{mol} \%)$ & $55-56$ & $41 \cdot 4$ & 42 & $37-38$ & $38-39$ & $41 \cdot 3$ & $34 \cdot 8$ \\
\hline
\end{tabular}

${ }^{\star}$ A, Obligate aerobe; F, facultative anaerobe.

$\dagger$ Grown on Marine agar 2216 for fatty acid analysis.

$\$ 16: 1 \omega 7 c+2-\mathrm{OH}$ i15:0.

2) demonstrated that the two HTCC strains represent a coherent and novel genus within the family Flavobacteriaceae. The phenotypic and genotypic characteristics of the strains generally met the minimal standards for the family Flavobacteriaceae (Bernardet et al., 2002). Furthermore, comparisons of phenotypic and chemotaxonomic characteristics between the phylogenetically associated genera indicated clearly that the isolates could not be placed in any of the previously described genera (Table 2 ). The property of the strains that best differentiated them from other members of the family Flavobacteriaceae was the DNA G + C content, which was more than $10 \mathrm{~mol} \%$ higher than those of the other genera within the family. In view of all the data presented in this study, the novel strains belong to a new genus and species within the family Flavobacteriaceae; therefore, we propose for them the name Robiginitalea biformata gen. nov., sp. nov.

\section{Description of Robiginitalea gen. nov.}

Robiginitalea (Ro.bi.gi.ni.tal'e.a. L. gen. n. robiginis of rust; L. fem. n. talea a rod; N.L. fem. n. Robiginitalea a rustcoloured rod).

Gram-negative. Morphology varies from straight rods, in exponential phase, to coccoid cells, in stationary phase. Cells do not exhibit motility or gliding motility. Oxidase- and catalasepositive. Carotenoid pigments are produced, but flexirubin pigments are not produced. Obligately aerobic and chemoheterotrophic. $\mathrm{NaCl}$ is required for growth. Starch and aesculin are degraded. The major fatty acid types are branched acids and hydroxy acids. The predominant fatty acids are i15:0 (24-28\%), i15:1 (14-21\%) and 3-OH i17:0 (25-27\%). DNA G + C content is 55-56 mol\%. Phylogenetically, a novel member of the family Flavobacteriaceae. The type and only species of the genus is Robiginitalea biformata. 


\section{Description of Robiginitalea biformata sp. nov.}

Robiginitalea biformata (bi.for.ma'ta. L. fem. adj. biformata double-formed, two-shaped, pertaining to the different cell morphology in different growth phases).

Description is the same as that for the genus with the following additional properties. Cells in exponential phase are straight rods, $1 \cdot 6-5 \cdot 6 \mu \mathrm{m}$ long and $0 \cdot 3-0 \cdot 7 \mu \mathrm{m}$ wide. Cells in stationary phase are coccoid, $0 \cdot 6-1 \cdot 2 \mu \mathrm{m}$ in diameter. Endospores and poly- $\beta$-hydroxybutyrate granules are not formed. Colonies are rusty-orange-coloured, circular, pulvinate and opaque. Growth occurs at $10-44^{\circ} \mathrm{C}$, but not at 4 or $48^{\circ} \mathrm{C}$. The $\mathrm{pH}$ and salinity ranges for growth are $6 \cdot 0-9 \cdot 0$ and $0 \cdot 25-10 \%(\mathrm{w} / \mathrm{v})$, respectively. Moderately halophilic. Maximum absorption spectral peak occurs at $457 \mathrm{~nm}$. No denitrification activity detected. A variety of carbon compounds are used as sole carbon sources, including pentoses, hexoses, oligosaccharides, sugar acids and amino acids. Cellular fatty acid composition, biochemical characteristics, sole-carbon-source utilization, antibiotic susceptibility and degradation of macromolecules are detailed in Table 1 . The DNA G+C content of the type strain, HTCC $2501^{\mathrm{T}}$, is $56 \cdot 4 \pm 0 \cdot 2 \mathrm{~mol} \%$ (HPLC method). Strains have been isolated from the western Sargasso Sea, Atlantic Ocean.

The type strain is $\mathrm{HTCC}^{2} 501^{\mathrm{T}}\left(=\mathrm{ATCC} \mathrm{BAA}-864^{\mathrm{T}}=\right.$ KCTC $12146^{\mathrm{T}}$ ).

\section{Acknowledgements}

We would like to thank Dr J. Euzéby for his recommendations about etymology. We are grateful to crews of the RV Weatherbird II for helping us collect sea-water samples. We are also grateful to K. Vergin and R. Morris for their helpful suggestions regarding the manuscript. This study was supported by grants from Diversa Corp. and a grant (DEB-0207085) from the National Science Foundation.

\section{References}

Barbeyron, T., L'Haridon, S., Corre, E., Kloareg, B. \& Potin, P. (2001). Zobellia galactanovorans gen. nov., sp. nov., a marine species of Flavobacteriaceae isolated from a red alga, and classification of [Cytophaga] uliginosa (Zobell and Upham 1944) Reichenbach 1989 as Zobellia uliginosa gen. nov., comb. nov. Int J Syst Evol Microbiol 51, 985-997.

Bernardet, J.-F., Nakagawa, Y. \& Holmes, B. (2002). Proposed minimal standards for describing new taxa of the family Flavobacteriaceae and emended description of the family. Int J Syst Evol Microbiol 52, 1049-1070.

Bowman, J. P. \& Nichols, D. S. (2002). Aequorivita gen. nov., a member of the family Flavobacteriaceae isolated from terrestrial and marine Antarctic habitats. Int J Syst Evol Microbiol 52, 1533-1541.

Bowman, J. P., McCammon, S. A., Brown, J. L., Nichols, P. D. \& McMeekin, T. A. (1997). Psychroserpens burtonensis gen. nov., sp. nov., and Gelidibacter algens gen. nov., sp. nov., psychrophilic bacteria isolated from Antarctic lacustrine and sea ice habitats. Int J Syst Bacteriol 47, 670-677.

Bowman, J. P., McCammon, S. A., Lewis, T., Skerratt, J. H., Brown, J. L., Nichols, D. S. \& McMeekin, T. A. (1998). Psychroflexus torquis gen. nov., sp. nov., a psychrophilic species from Antarctic sea ice, and reclassification of Flavobacterium gondwanense (Dobson et al. 1993) as Psychroflexus gondwanense gen. nov., comb. nov. Microbiology 144, 1601-1609.

Bruns, A., Rohde, M. \& Berthe-Corti, L. (2001). Muricauda ruestringensis gen. nov., sp. nov., a facultatively anaerobic, appendaged bacterium from German North Sea intertidal sediment. Int J Syst Evol Microbiol 51, 1997-2006.

Cho, J.-C. \& Giovannoni, S. J. (2003a). Croceibacter atlanticus gen. nov., sp. nov., a novel marine bacterium in the family Flavobacteriaceae. Syst Appl Microbiol 26, 76-83.

Cho, J.-C. \& Giovannoni, S. J. (2003b). Fulvimarina pelagi gen. nov., sp. nov., a marine bacterium that forms a deep evolutionary lineage of descent in the order 'Rhizobiales'. Int J Syst Evol Microbiol 53, 1853-1859.

Cottrell, M. T. \& Kirchman, D. L. (2000). Natural assemblages of marine proteobacteria and members of the Cytophaga-Flavobacter cluster consuming low- and high-molecular-weight dissolved organic matter. Appl Environ Microbiol 66, 1692-1697.

Eilers, H., Pernthaler, J., Glöckner, F. O. \& Amann, R. (2000). Culturability and in situ abundance of pelagic bacteria from the North Sea. Appl Environ Microbiol 66, 3044-3051.

Garrity, G. M. \& Holt, J. G. (2001). The road map to the Manual. In Bergey's Manual of Systematic Bacteriology, 2nd edn, vol. 1, pp. 119-166. Edited by D. R. Boone, R. W. Castenholz \& G. M. Garrity. New York: Springer.

Glöckner, F. O., Fuchs, B. M. \& Amann, R. (1999). Bacterioplankton compositions of lakes and oceans: a first comparison based on fluorescence in situ hybridization. Appl Environ Microbiol 65, 3721-3726.

Gosink, J. J., Woese, C. R. \& Staley, J. T. (1998). Polaribacter gen. nov., with three new species, $P$. irgensii sp. nov., $P$. franzmannii sp. nov. and $P$. filamentus sp. nov., gas vacuolate polar marine bacteria of the Cytophaga-Flavobacterium-Bacteroides group and reclassification of 'Flectobacillus glomeratus' as Polaribacter glomeratus comb. nov. Int J Syst Bacteriol 48, 223-235.

Ivanova, E. P., Nedashkovskaya, O. I., Chun, J. \& 7 other authors (2001). Arenibacter gen. nov., new genus of the family Flavobacteriaceae and description of a new species, Arenibacter latericius sp. nov. Int J Syst Evol Microbiol 51, 1987-1995.

Johansen, J. E., Nielsen, P. \& Sjøholm, C. (1999). Description of Cellulophaga baltica gen. nov., sp. nov. and Cellulophaga fucicola gen. nov., sp. nov. and reclassification of [Cytophaga] lytica to Cellulophaga lytica gen. nov., comb. nov. Int J Syst Bacteriol 49, 1231-1240.

Ludwig, W., Strunk, O., Klugbauer, S., Klugbauer, N., Weizenegger, M., Neumaier, J., Bachleitner, M. \& Schleifer, K. H. (1998). Bacterial phylogeny based on comparative sequence analysis. Electrophoresis 19, 554-568.

McCammon, S. A. \& Bowman, J. P. (2000). Taxonomy of Antarctic Flavobacterium species: description of Flavobacterium gillisiae sp. nov., Flavobacterium tegetincola sp. nov. and Flavobacterium xanthum sp. nov., nom. rev. and reclassification of [Flavobacterium] salegens as Salegentibacter salegens gen. nov., comb. nov. Int J Syst Evol Microbiol 50, 1055-1063.

Mesbah, M., Premachandran, U. \& Whitman, W. B. (1989). Precise measurement of the $\mathrm{G}+\mathrm{C}$ content of deoxyribonucleic acid by high-performance liquid chromatography. Int J Syst Bacteriol 39, 159-167.

Nedashkovskaya, O. I., Suzuki, M., Vysotskii, M. V. \& Mikhailov, V. V. (2003a). Vitellibacter vladivostokensis gen. nov., sp. nov., a new member of the phylum Cytophaga-Flavobacterium-Bacteroides. Int J Syst Evol Microbiol 53, 1281-1286. 
Nedashkovskaya, O. I., Kim, S. B., Han, S. K. \& 7 other authors (2003b). Mesonia algae gen. nov., sp. nov., a novel marine bacterium of the family Flavobacteriaceae isolated from the green alga Acrosiphonia sonderi (Kütz) Kornm. Int J Syst Evol Microbiol 53, 1967-1971.

Nedashkovskaya, O. I., Kim, S. B., Han, S. K., Rhee, M. S., Lysenko, A. M., Falsen, E., Frolova, G. M., Mikhailov, V. V. \& Bae, K. S. (2004). Ulvibacter litoralis gen. nov., sp. nov., a novel member of the family Flavobacteriaceae isolated from the green alga Ulva fenestrata. Int J Syst Evol Microbiol 54, 119-123.

Reichenbach, H. (1989). Order I. Cytophagales Leadbetter 1974, $99^{\mathrm{AL}}$. In Bergey's Manual of Systematic Bacteriology, vol. 3, pp. 2011-2013. Edited by J. T. Staley, M. P. Bryant, N. Pfennig \& J. C. Holt. Baltimore: Williams \& Wilkins.

Vandamme, P., Pot, B., Gillis, M., De Vos, P., Kersters, K. \& Swings, J. (1996). Polyphasic taxonomy, a consensus approach to bacterial systematics. Microbiol Rev 60, 407-438.

Van Trappen, S., Vandecandelaere, I., Mergaert, J. \& Swings, J. (2004). Gillisia limnaea gen. nov., sp. nov., a new member of the family Flavobacteriaceae isolated from a microbial mat in Lake Fryxell, Antarctica. Int J Syst Evol Microbiol 54, 445-448.

Wayne, L. G., Brenner, D. J., Colwell, R. R. \& 9 other authors (1987). International Committee on Systematic Bacteriology. Report of the ad hoc committee on reconciliation of approaches to bacterial systematics. Int J Syst Bacteriol 37, 463-464. 